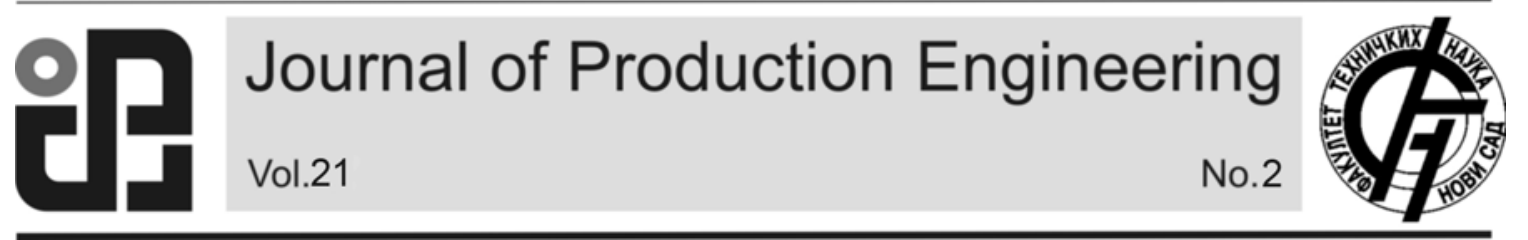

JPE (2018) Vol.21 (2)

Victor A. Adedayo

Original Scientific Paper

\title{
INFLUENCE OF TEMPERATURE OF QUENCHANT ON SOME MECHANICAL PROPERTIES OF MEDIUM CARBON STEEL
}

Received: 10 September 2018 / Accepted: 17 November 2018

\begin{abstract}
The study investigated influence of temperature of quenching water on some mechanical properties of medium carbon steel was investigated. The mechanical properties investigated are hardness, toughness and tensile strength. The medium carbon steel samples were machined to required dimensions and heated to austenization temperature of $930^{\circ} \mathrm{C}$ and quenched in water maintained at temperatures of $0^{\circ} \mathrm{C}, 35^{\circ} \mathrm{C}$, and $100^{\circ} \mathrm{C}$. Control samples were also machined, but not heat-treated. The mechanical properties of the quenched and control samples were determined through standard property evaluation procedures. The results show that the mechanical properties are dependent on the temperature of the quenchant water used. The microstructures also show a dependence on the temperature of the quenchant.
\end{abstract}

Key words: mechanical properties, carbon steel, microstructures, temperature.

Uticaj temerature vode za kaljenje na neke mehaničke osobine ugljeničnog čelika sa srednjim procentom ugljenika. Studija ispitivanja uticaja temperature kaljene vode na neke mehaničke osobine ugljeničnog čelika sa srednjim procentom ugljenika. Ispitivane su mehaničke osobine čvrstoće, žilavost i zatezna čvrstoća. Uzorci srednjeg ugljeničnog čelika obrađeni su prema potrebnim dimenzijama i zagrejani do temperature austenizacije $930^{\circ} \mathrm{C}$, hlađenje je vršeno u vodi temperature $0^{\circ} \mathrm{C}, 35^{\circ} \mathrm{C}$ i $100^{\circ} \mathrm{C}$. Kontrolni uzorci su takođe obrađeni, ali nisu termički tretirani. Mehaničke osobine termički tretiranih i kontrolnih uzoraka određene su standardnim procedurama određivanja mehaničkih svojstava materijala. Rezultati pokazuju da mehanička svojstva zavise od temperature vode za hlađenje. Mikrostruktura takođe pokazuju zavisnost temperature vode za hlađenje.

Ključne reči: mehaničke osobine, ugljenični čelik, mikrostrukture, temperatura.

\section{INTRODUCTION}

Heat treatment involves subject a material to a definite thermal cycle which may be divided into three parts: Heating, Holding at a temperature (soaking) and cooling. The main objective of heat treatment is to modify the properties of the materials heat treated. Material properties such as mechanical, physical, and chemical properties have all been reported to be modifiable by heat treatment (AZoM, 2003). Heat treatment is a general term that applies to procedures that employ subjecting materials to thermal cycles. There is a significant agreement in the literatures that the purpose of heat treatment is to influence the property of the material (Adedayo et al., 2010; Rajput, 2006; Brooks, 1982). While there are common agreeable features to the definitions of heat treatment, however, definitions in some literatures contain specifics that call for careful attention to the definition of heat treatment. Wisconsin Oven Corporation (2014) and Rajput (2006) specify that heat treatment must be carried out while the material is in the solid state, with the objective to alter the property of the material. In this context, thermal processes in which materials are heated to semi solid state, such as thixocasting, should not be considered as heat treatment processes. However, USPTO (1996) stated that thixocasting is a heating treatment process used to prepare a material to have characteristic semi solid microstructure.

Also, heating for the sole purpose of hot working such as in rolling, forging and extrusion is excluded from the meaning of this definition (Wisconsin Oven Corporation 2014). The definition of heat treatment by Wisconsin Oven Corporation (2014) has also been adopted by American Foundrymen's Association, the American Society for Metals, the American Society for Testing and the Society of Automotive Engineers (Wisconsin Oven Corporation 2014). Specific procedures have been identified to impart specific properties in heat treated materials. Some of these procedures include: annealing, normalizing, tempering, austempering, martempering and hardening etc. The main feature of hardening is rapid cooling by quenching. The severity of quenching affects the hardness of the quenched material. Therefore, any means of varying the severity of quenching will influence the hardness value of the quenched material. Normally, the degree of hotness of a medium will affects the rate of cooling, therefore quenching with media of different temperature will affect the hardness of a material. Herein the rationale for the study is identified.

\section{EXPERIMENTAL PROCEDURE}

The material used for the study is NST $60 \mathrm{Mn}$ steel of $150 \mathrm{~mm}$ in length and $12 \mathrm{~mm}$ diameter. This steel material was obtained from Oshogbo steel rolling mill, Nigeria. The chemical composition of this steel is presented in Table 1. This steel material was then 
machined on a lathe machine to produce ASTM E8M88 standard test samples (Figure 1) for Impact, hardness and tensile strength. The test samples were produced using High Speed Steel (HSS) cutting tool, with a cutting speed of 305 revolutions per minute. Micrometer screw gauge and vernier calipers were used for measuring the dimensions of the machined samples. The produced samples were then heated in a lift - out crucible furnace to austenitization temperature of $930^{\circ} \mathrm{C}$, soaked at this temperature for 1 hour, and quenched in buckets filled with water maintained at temperatures: 0 , 35 , and $100^{\circ} \mathrm{C}$. Control samples which were not quenched in water were also prepared. All the prepared samples were then evaluated for toughness, hardness and tensile strength. The microexamination of the microstructure of the samples was also carried out with computerized Olympus microscope.

\begin{tabular}{|c|c|c|c|c|c|c|c|c|c|c|c|c|}
\hline Element & $U$ & $\bar{\sim}$ & $\Xi$ & is & $a$ & $\bar{z}$ & $\stackrel{\circ}{\Sigma}$ & ت & क & ن & $\dot{U}$ & 至 \\
\hline $\begin{array}{c}\% \\
\text { Compositio }\end{array}$ & $\stackrel{\mathcal{Y}}{\circ}$ & ?̊ & @̊ & $\begin{array}{l}n \\
0 \\
0\end{array}$ & $\stackrel{n}{0}$ & $\stackrel{0}{0}$ & $\stackrel{ }{0}$ & $\stackrel{\infty}{\sim}$ & $\hat{0}$ & $\begin{array}{l}8 \\
0 \\
0 \\
0\end{array}$ & $\frac{0}{0}$ & 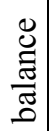 \\
\hline
\end{tabular}

Table 1. Chemical composition of the medium carbon steel sample

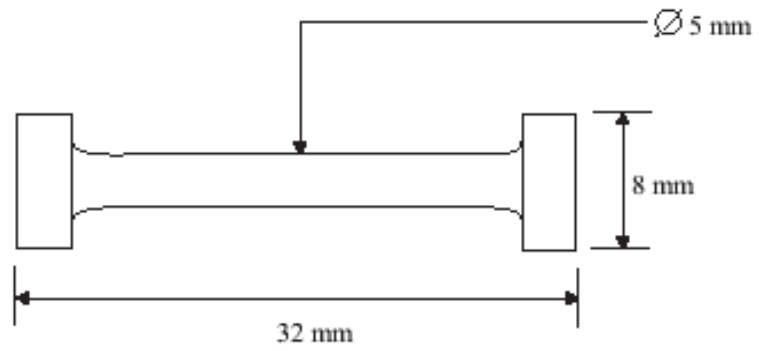

Fig. 1. Dimensions of ASTM E8M-88 standard tensile test pieces used

\section{RESULT AND DISCUSION}

Tables and Figures 2, 3, and 4 show the variation of the evaluated mechanical properties, while Figures 5, 6, 7 , and 8 show the stress-strain curves of the samples evaluated. Figures 9, 10, 11, and 12 are the microstructures of the samples used for the experiment.

\begin{tabular}{|c|c|c|c|}
\hline 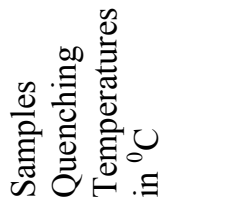 & 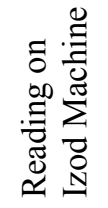 & 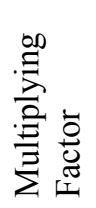 & 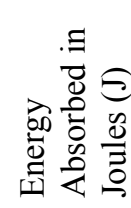 \\
\hline 0 & 6.7 & 1.37 & 9.18 \\
\hline 35 & 8.4 & 1.37 & 11.51 \\
\hline 100 & 18.7 & 1.37 & 25.62 \\
\hline Control sample & 45.7 & 1.37 & 62.61 \\
\hline
\end{tabular}

Table 2. Impact test result

Table and Figure 2 present the variation of toughness values of the sample with the temperature of the quenching water. The information presented showed that the toughness of the steel increases with increase in the temperature of the quenching medium, this because the increase in temperature of the quenching media reduces the quench severity on the quenched samples, thereby reducing hardening of the quenched sample which also lead to improved toughness.

Table and Figure 3 show variation of the Brinell hardness values of the samples with the temperature of the quenching water. The information presented showed that the hardness of the samples decreases with increase in temperature of the quenching medium, this because increased temperature reduces severity of quenching which results in less hardening of the samples

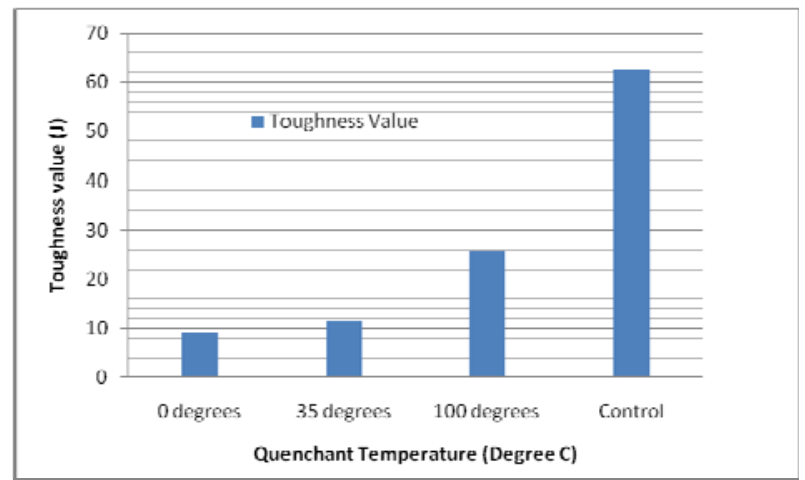

Fig. 2. Variation of toughness value with quenchant temperature

\begin{tabular}{|c|c|c|}
\hline 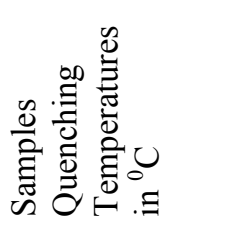 & 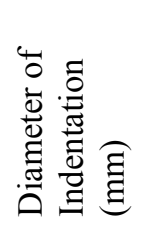 & 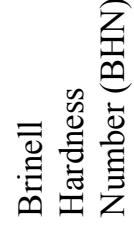 \\
\hline 0 & 2.0 & 229 \\
\hline 35 & 2.2 & 187 \\
\hline 100 & 2.6 & 131 \\
\hline Control sample & 2.8 & 111 \\
\hline
\end{tabular}

Table 3. Hardness test result

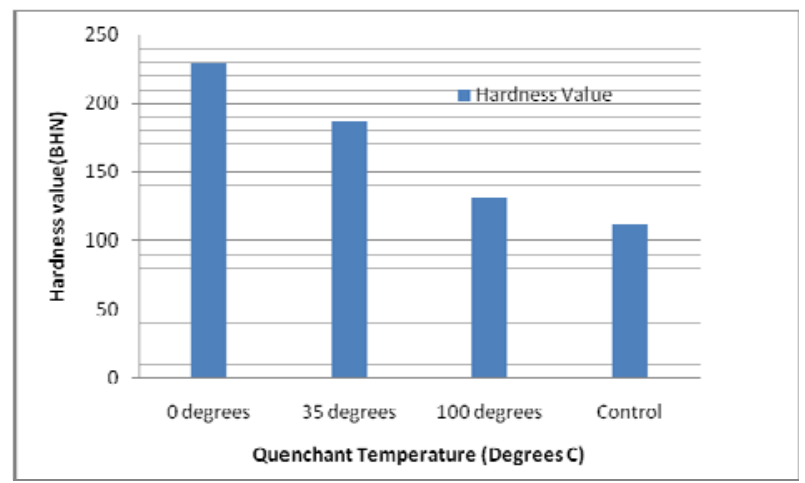

Fig. 3. Variation of hardness value with quenchant temperature

Table and Figure 4 show variation of tensile strength of the samples with the temperature of the quenchant. It shows that tensile strength reduces with increase in the temperature of the quenchant. 


\begin{tabular}{|c|c|c|c|c|c|c|c|c|}
\hline $\begin{array}{c}\text { Quenchant } \\
\text { temperatures } \\
\left({ }^{0} \mathrm{C}\right)\end{array}$ & $\begin{array}{c}\text { Initial } \\
\text { length } \\
\mathrm{L}_{0} \\
(\mathrm{~mm})\end{array}$ & $\begin{array}{c}\text { Final } \\
\text { length } \\
\mathrm{L}_{\mathrm{f}} \\
(\mathrm{mm})\end{array}$ & $\begin{array}{c}\text { Change } \\
\text { in length } \\
\partial \mathrm{L}(\mathrm{mm})\end{array}$ & $\begin{array}{c}\text { Initial } \\
\text { diameter } \\
\mathrm{D}_{0}(\mathrm{~mm})\end{array}$ & $\begin{array}{c}\text { Final } \\
\text { diameter } \\
\mathrm{D}_{\mathrm{f}}(\mathrm{mm})\end{array}$ & $\begin{array}{c}\text { Change in } \\
\text { diameter } \\
\partial \mathrm{D}(\mathrm{mm})\end{array}$ & $\begin{array}{c}\text { Original } \\
\text { Cross- } \\
\text { sectional } \\
\text { area } \\
\left(\mathrm{mm}^{-2}\right)\end{array}$ & $\begin{array}{c}\text { Tensile } \\
\text { strength } \\
\left(\mathrm{Nmm}^{-2}\right)\end{array}$ \\
\hline 0 & 37.58 & 37.95 & 0.37 & 5.12 & 5.08 & 0.40 & 20.6 & 91.26 \\
\hline 35 & 37.52 & 38.44 & 0.92 & 5.16 & 4.71 & 0.45 & 20.9 & 80.38 \\
\hline 100 & 38.92 & 41.11 & 2.19 & 5.32 & 4.79 & 0.53 & 22.23 & 71.10 \\
\hline Control sample & 37.41 & 43.32 & 5.91 & 5.20 & 3.70 & 1.50 & 21.24 & 44.26 \\
\hline
\end{tabular}

Table 4. Tensile test result

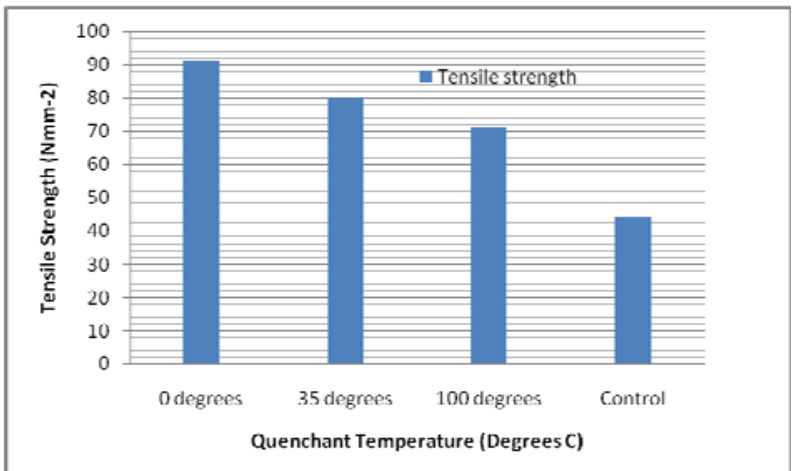

Fig. 4. Variation of tensile strength with quenchant temperature

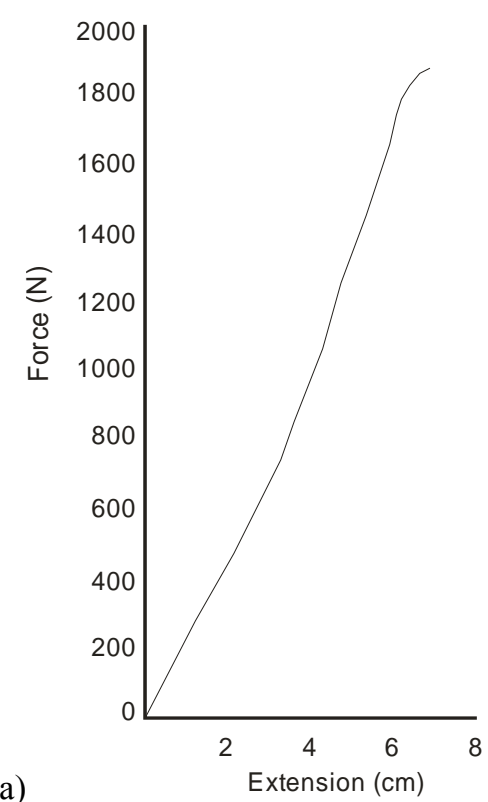

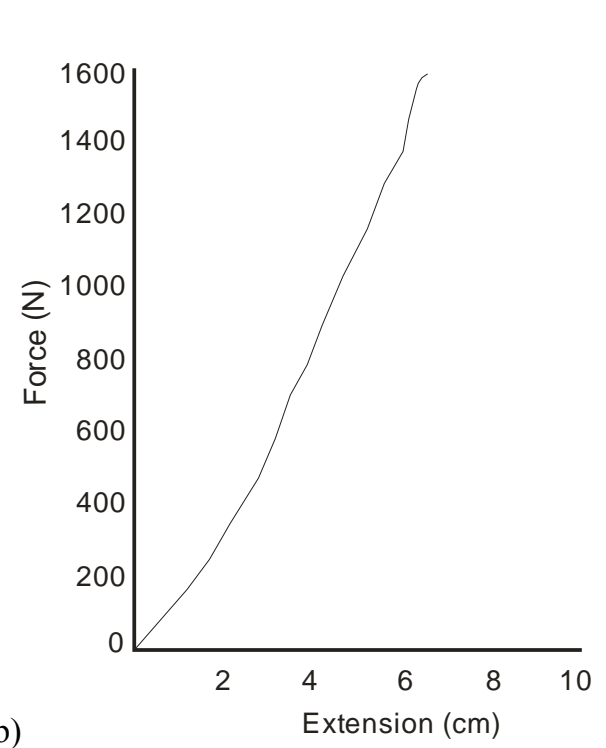

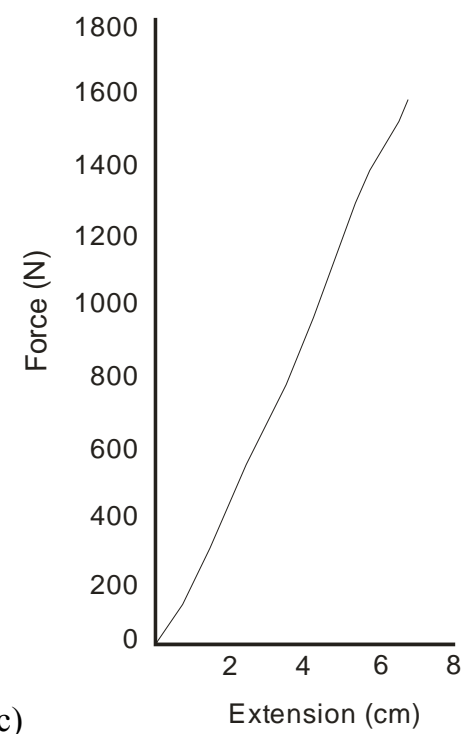

Fig. 5. Stress-Strain curve of sample quenched in water of, a) $0^{\circ} \mathrm{C}$, b) $35^{\circ} \mathrm{C}$, c) $100^{\circ} \mathrm{C}$

Figures $5(\mathrm{a}, \mathrm{b}, \mathrm{c})$ and 6 present the Stress-Strain curves of the tested samples. The Stress-Strain curves of the quenched samples showed a typical curve for a brittle material, while the curve for the control sample is a typical curve for ductile materials.

This shows that, by reason of quenching of these treated samples, there ductility has reduced due to hardening.

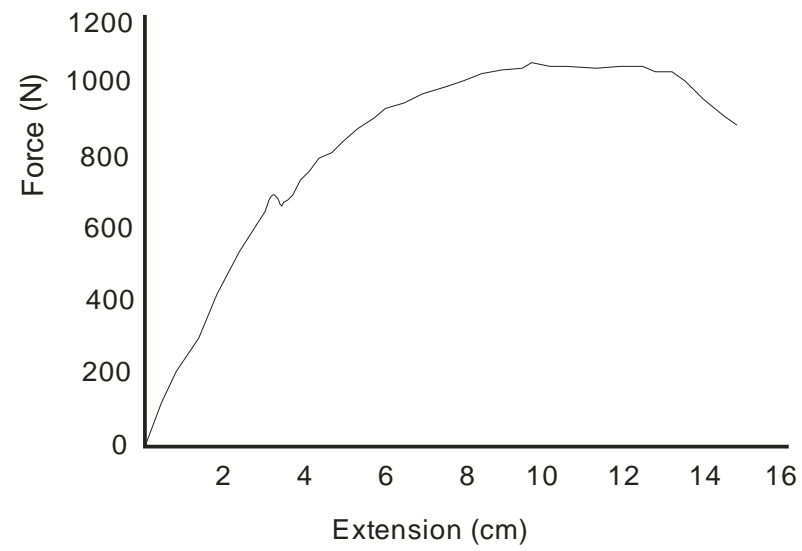

Fig. 6. Stress-Strain curve of the control sample
Figures 7, 8, and 9 show the microstructures of the quenched samples; while Figure 10 shows the microstructure of the control sample. These microstructures are essentially ferritic. Ferritic structures can be: Massive ferrite, Idiomorphic ferrite, Allotriomorphic ferrite, Martcnsitic, Widmanstatten Ferrite, Bainite, Acicular ferrite etc (Ali, 1991; IIW, 1988; da Trindade Filho et al., 2004). Normally, steels are hardened by rapid cooling from austenitic temperature. By rapid cooling, carbon atoms are trapped in the austenite to form extremely strained structure of iron. 


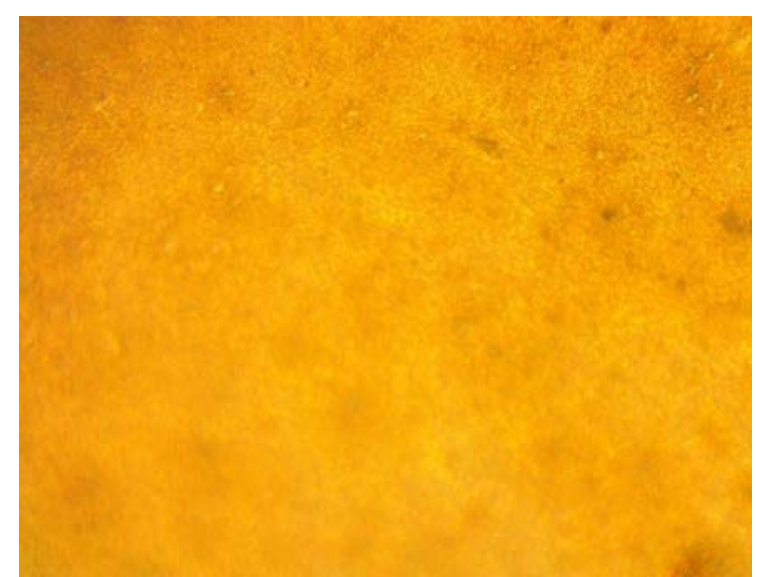

Fig. 7. Micrograph of sample quenched at $0^{\circ} \mathrm{C}$

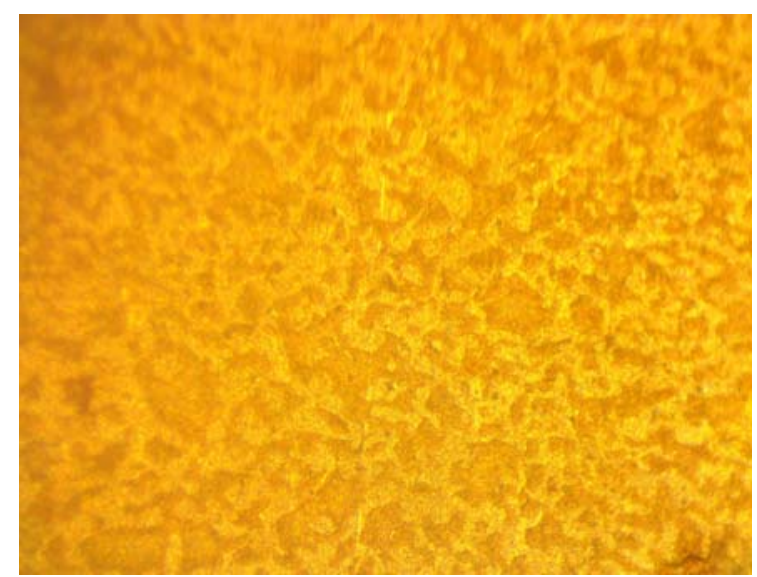

Fig. 8. Micrograph of sample quenched at $35^{\circ} \mathrm{C}$

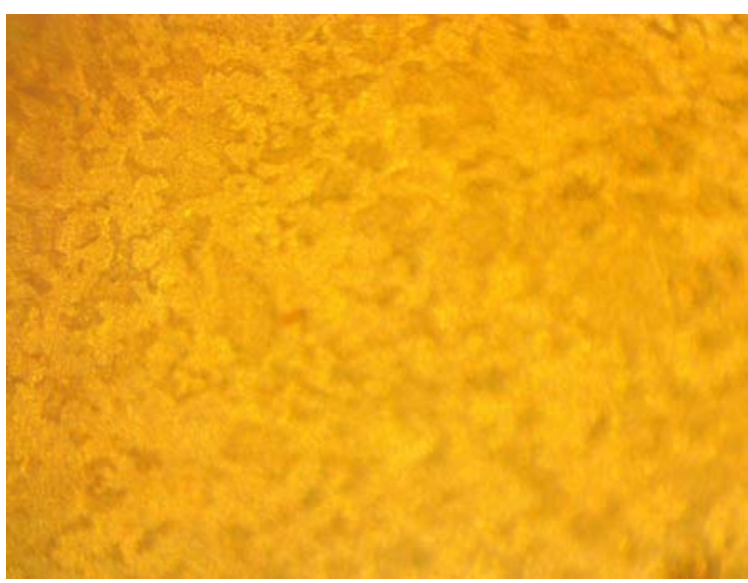

Fig. 9. Micrograph of sample quenched at $100^{\circ} \mathrm{C}$

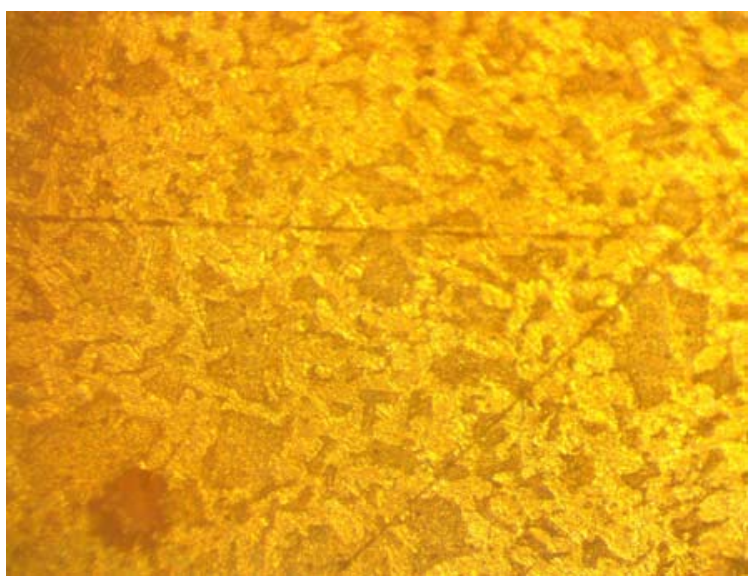

Fig. 10. Micrograph of control sample

\section{CONCLUSION}

The result of the study shows that the temperature of the quenching medium can significantly affect the mechanical properties of steel. There was significant modification of the microstructures, thus showing a dependence of microstructure on the temperature of the quenchant. Generally, increased temperature of the quenchant reduced the hardness and tensile strength, while the toughness increased with increase in temperature.

\section{REFERENCES}

[1] Adedayo, A.V., Ibitoye, S.A., Oyetoyan, O.A. (2010) Annealing Heat Treatment Effects on Steel Welds. Journal of Mineral, Materials Characterization and Engineering, Vol. 9, No. 6 pp 601-611.

[2] Ali, A. (1991) Widmanstatten ferrite and bainite in ultra high strength steels, $\mathrm{A} \mathrm{PhD}$ Thesis, Department of Materials Science and Metallurgy, Cambridge University

[3] AZoM, (2003) Heat Treatment of Metals - Why Heat Treat Metals? Retrieved on: $2^{\text {nd }}$ September, 2018,

from: https://www.azom.com/article.aspx?ArticleID=21 $\underline{97}$

[4] Brooks C. R., (1982) Heat Treatment: Structure and Properties of Nonferrous Alloys, A. S. M. Publication.

[5] International Institute of Welding (1988) Guidelines for the classification of ferrite steel weld metal microstructure constituents using the light microscopy, International Institute of Welding, IIW DOC. IX-1533-88.

[6] Rajput, R.K. (2006) Engineering materials and metallurgy, $1^{\text {st }}$ ed. S. Chand \& Co. New Delhi

[7] da Trindade Filho V.B., A.S. Guimaraes, J. da C. Payao Filho, R.P. da R. Paranhos (2004) Normalizing heat treatment effects on low alloy steel weld metals. Journal of Brazilian Society of Mechanical Sciences and Engineering, Vol. 26., No. 1, pp. 62-66

[8] USPTO (1996) United States Patent and Trademark Office: US5803154A

[9] Wisconsin Oven Corporation (2014) Heat Treat Definitions, Available at: http://www.wisoven.com/technical/heat-treatdefinitions (Accessed on: 24th July, 2018)

Authors: Victor A. Adedayo ${ }^{1,2},{ }^{I}$ Department of Materials Science and Engineering; Obafemi Awolowo University, Ile-Ife, Nigeria, ${ }^{2}$ Department of Metallurgical Engineering; Kwara State Polytechnic, PMB 1375, Ilorin, Nigeria

E-mail: a.v.adedayo@gmail.com adedayo2187@kwarastatepolytechnic.edu.ng 